Original Research Paper

\title{
Edukasi dan Pelatihan Pengembangan Produk Olahan Selai Lembar Berbasis Kombinasi Daging dan Kulit Buah Naga Merah pada Kelompok Wanita Tani (KWT) Kebun Buah Naga di Desa Tanak Beak Lombok Tengah
}

\author{
Lalu Zulkifli $^{1 *}$, Dewa Ayu Citra Rasmii ${ }^{1}$, Mahrus $^{1}$, Syamsul Bahri $^{1}$, Ahmad Raksun ${ }^{1}$

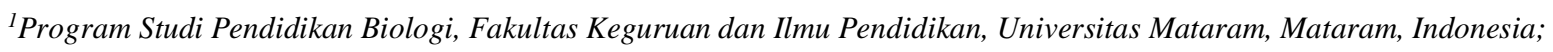

https://doi.org/10.29303/jpmpi.v3i2.1108

Sitasi: Zulkifli, L., Rasmi, D. A. C., Mahrus., Bahri, S \& Raksun, A. (2021). Edukasi dan Pelatihan Pengembangan Produk Olahan Selai Lembar Berbasis Kombinasi Daging dan Kulit Buah Naga Merah pada Kelompok Wanita Tani (KWT) Kebun Buah Naga di Desa Tanak Beak Lombok Tengah. Jurnal Pengabdian Magister Pendidikan IPA 4(4)

\author{
Article history \\ Received: 02 Oktober 2021 \\ Revised: 20 Oktober 2021 \\ Accepted: 07 November 2021 \\ *Corresponding Author: Lalu \\ Zulkifli, Program Studi \\ Pendidikan Biologi, Fakultas \\ Keguruan dan Ilmu Pendidikan, \\ Universitas Mataram, Mataram, \\ Indonesia; \\ Email: \\ lalu_zulkifli@unram.ac.id
}

\begin{abstract}
Desa Tanak Beak Kecamatan Batukliang Utara merupakan salah satu sentra penghasil buah naga di Lombok Tengah. Desa ini memiliki Kebun Buah Naga yang dikelola oleh Kelompok Wanita Tani (KWT) Mekar Indah. Dengan adanya pandemi Covid-19 ini mengakibatkan turun drastisnya pengunjung kebun mengakibatkan adanya over produksi, dan harga di pasaran menjadi menurun. Tujuan pengabdian ini adalah membantu masyarakat dalam menangani permasalahan pasca panen buah naga dan memberikan keterampilan terkait teknologi pengembangan variasi produk olahan dari buah naga dengan mengikutsertakan komponen kulit sebagai bahan dasar olahan. Salah satu produk makanan olahan dengan mengkombinasikan daging buah dan kulit buah naga adalah selai lembar buah naga merah yang lebih praktis jika dibandingkan dengan selai dalam kemasan botol. Edukasi dan pelatihan pembuatan produk olahan dan teknik pengemasan sehingga dapat juga bernilai ekonomi skala rumah tangga. Metode pelaksanaan berupa metode partisipatif dengan kegiatan penyuluhan dan praktek pembuatan produk selai lembaran. Dalam pelaksaaan kegiatan pengabdian ini, dihadiri oleh sekitar 20 anggota KWT. Selama kegiatan berlangsung, para partisipan mengikuti dengan seksama materi yang dijelaskan oleh tim, baik materi teori penanganan pasca panen buah naga dan praktek langsung pembuatan produk olahan kombinasi daging kulit buah naga (dengan proporsi 70\%:30\%). Diakhir kegiatan peserta juga mencicipi produk hasil praktek dengan roti tawar. Hasil evaluasi dari kegiatan secara keseluruhan menunjukkan bahwa semua anggota KWT Mekar Indah akan melanjutkan keterampilan yang diperolehnya agar dapat menjadi usaha kecil yang dapat membantu perekonomian keluarga. Mereka juga termotivasi karena semua alat-alat perlengkapan untuk produksi selai lembaran diberikan oleh tim pengabdian.
\end{abstract}

Keywords: Selai lembaran, Buah naga merah, KWT Mekar Indah

\section{Pendahuluan}

Desa Tanak Beak adalah salah satu desa yang secara administratif masuk dalam wilayah Kecamatan Batukliang Lombok Tengah. Desa Tanak Beak terletak di sebelah utara Kabupaten
Lombok Tengah, berjarak sekitar $25 \mathrm{Km}$ meter dari Praya (ibu kota kabupaten). Desa Tanak Beak terdiri dari 10 Dusun: yaitu Dusun Tanak Beak Timur, Dusun Tanak Beak Barat, Dusun Ceking, Dusun Mandok, Dusun Parampuan, Dusun Jurang Tangkluk, Dusun Montong Tanggak, Dusun Dasan Agung, Dusun Tanak Bengan, Dusun Dasan Agung 
Kebon Indah (tempat wisata alam buah naga). Desa Tanak Beak dikelilingi oleh Desa Aik Darek Kec. Batukliang (Selatan), Desa Karang Sidemen, Kec. Batukliang Utara (Timur), Desa Pemepek Kec. Pringgarata (Barat dan Utara). Jumlah total penduduk yang terdata sampai tahun 2018 adalah 6960 jiwa dengan rincian 3445 lakilaki dan 3515 perempuan. Mata pencaharian masyarakat desa Tanak Beak didominasi oleh petani dan buruh tani (sekitar 60\%) dan diikuti oleh pedagang (Profil Desa Tanak Beak, 2018).

Desa Tanak Beak tergolong cukup berhasil dalam mengembangkan wisata kebun naga khususnya yang berlokasi di Dusun Dasan Agung Kebun Indah. Di lokasi ini banyak sekali terdapat tanaman buah naga dengan lahan seluas lebih dari 1 hektar yang dapat memproduksi sekitar 3 Ton untuk sekali panen. Dalam setahun dapat dilakukan 3 kali panen. Khusus di kawasan tersebut buahnya tidak dijual ke pengepul melainkan langsung di konsumsi di tempat oleh para wisatawan. Pengunjung yang berdatangan tidak hanya wisatawan domestik tapi banyak juga dari mancanegara untuk menikmati indahnya alam dan menikmati daging buah naga. Hal ini mengakibatkan banyaknya kulit buah naga yang terbuang dan menjadi limbah perkebunan yang terbuang tidak termanfaatkan.

Buah naga merupakan buah yang banyak digemari oleh masyarakat karena memiliki khasiat dan manfaat serta nilai gizi yang cukup tinggi. Buah naga merah hanya dikonsumsi daging buahnya dalam keadaan segar, sedangkan limbah kulitnya yang berjumlah sekitar 30-35\% dari berat buah tidak dimanfaatkan (Dara et al., 2012; Pribadi et al., 2014). Kulit buah naga merah juga kaya akan sumber polipenol dan antioksidan. Produk olahan yang berbasis kulit buah naga ini juga memiliki arti penting dalam mengurangi limbah rumah tangga. Banyak laporan bahwa kulit buah naga mengandung banyak zat antibakteri dan antioksidan (khususnya flavonoid) yang dapat berperan sebagai agen antikanker (Sarasmita dan Laksmiani., 2015). Buah naga merah segar memiliki kadar air tinggi dan daya simpan yang terbatas, sehingga diperlukan pengolahan buah naga merah agar dapat memperpanjang daya simpan. Buah naga merah dapat diolah menjadi selai lembar agar memiliki daya tahan lebih lama. Kulit buah naga beratnya sekitar 30-35\% dari berat buah (Pribadi et al, 2014) dengan warnanya yang merah dapat juga dijadikan produk pangan berupa selai lembar, karena kulit buah naga mengandung pektin cukup tinggi $10.79 \%$.

Komposisi nilai gizi kandungan gula pada kulit buah naga merah berpotensi sebagai bahan baku pengolahan pangan, seperti olahan sirup kulit buah naga, selai kulit buah naga, manisan kulit buah naga, nata kulit buah naga (Nata de pitaya), atau produk berbahan dasar kombinasi dengan daging dan kulit yang dibuat menjadi selai buah naga merah. Disamping itu, pengemasan dan pelabelan produk olah juga sangat penting agar dapat menambah nilai ekonomi. Menurut Rahmawati (2013), pengemasan merupakan salah satu cara untuk melindungi atau mengawetkan produk pangan maupun non-pangan. Kemasan adalah suatu wadah atau tempat yang digunakan untuk mengemas suatu produk yang dilengkapi dengan label atau keterangan-keterangan termasuk beberapa manfaat dari isi kemasan. Pengemasan mempunyai peranan dan fungsi yang penting dalam menunjang distribusi produk terutama yang mudah mengalami kerusakan (Agustina, W.2009).

Diversifikasi produk olahan buah naga ini sangat diperlukan agar hasil panen tidak banyak yang rusak. Penjualan di pasar jika musim panen harganya menjadi sangat rendah, karena menjamurnya usaha perkebunan buah naga di pulau Lombok. Belum lagi bersaing dengan produk buah naga yang didatangkan dari Bali dan Jawa Timur. Dalam masa pandemi Covid-19 ini juga mengakibatkan turun drastisnya kunjungan wisatawan ke sentra kebun buah naga. Dua hal utama di atas mengakibatkan banyak buah naga yang tidak terjual. Berkaitan dengan hal di atas maka petani KWT perlu diberikan penyuluhan dan pelatihan terkait penanganan pasca panen buah naga yang baik, termasuk pembuatan selai lembar buah naga berbasis kombinasi daging dan kulit buah naga, serta penjelasan tentang bagaimana pengemasan produk yang baik.

\section{Metode}

\section{Persiapan}

Persiapan rencana program pengabdian pada masyarakat di Desa Tanak Beak tentang penyuluhan dan pelatihan pembuatan nata de pitaya dari limbah kulit buah naga meliputi: persiapan materi penyuluhan dan pelatihan, mengurus surat izin pengadian, konsolidasi 
dengan pemerintah desa setempat, Kadus Dasan Agung Kebon Indah dan ketua kelompok KWT kebun naga sebagai kelompok masyarakat sasaran.

\section{Pelaksanaan}

Metode yang akan digunakan adalah:

1. Sosialisasi dan penyuluhan: a). mengenai penanganan pasca panen buah naga yang baik, b). Kandungan Gizi daging dan kulit buah naga merah dan manfaatnya untuk kesehatan. c). Pengembangan produk olahan dari bahan baku buah naga, seperti pembuatan selai berkualitas baik dari kombinasi daging buah naga dan kulit buah naga. d). prinsip pengemasan agar produk dapat bernilai jual skala kecil.

2. Praktek langsung pembuatan selai lembaran. Dalam kegiatan ini kepada partisipan dijelaskan alat-alat dan bahan yang diperlukan, dan praktek pembuatan selai lembar dengan proporsi daging dan kulit buah dengan proporsi 70\%:30\%, dan mendemonstarsi kan bagaimana cara pengemasan yang baik agar produk selai lembar dapat bernilai jual.

3. Tahap evaluasi dan pelaporan. Evaluasi terhadap keberhasilan kegiatan langsung di lakukan setelah kegiatan selesai dengan berdiksusi dan tanya jawab terkait tanggapan dan harapan anggota KWT setelah kegiatan pengabdian dilakukan.

\section{Hasil dan Pembahasan}

\section{Analisa Hasil \\ 1. Sosialisasi dan penyuluhan penanganan pasca panen buah naga merah}

Pada tahap sosialisasi ini sekitar 20 anggota KWT Kebun buah naga Dusun Dasan Agung hadir (Gambar 1). Mereka sangat antusias dalam mengikuti penjelasan terkait penanganan pasca panen buah naga merah dan bagaimana cara mengatasi hasil panen yang berlebih melalui pembuatan produk olahan berbahan dasar daging dan kulit buah naga. Sambutan mereka sangat baik terkait program pengabdian ini, karena mereka materi ini juga penting dalam mengatasi limbah buah naga yang ketika panen banyak kulit buah naga yang menjadi limbah dan tidak termanfaatkan dan menjadikan lingkungan sekitar kurang baik. Dalam menyampaikan teknik pembuatan kami sampaikan melalui presentasi PPT, sehingga mereka lebih mudah menangkap pesan dan inti dari tahap-tahap proses dalam pembuatan selai lembar berhan dasar daging dan kulit buah naga. Dalam penjelasan teknik pembuatan selai lembaran terjadi diskusi dengan partisipan karena beberapa diantaranya juga sudah pernah mengikuti pelatihan pembuatan selai dengan kemasan botolan. Disamping itu mereka bertanya sampai pada tahap produksi dan kualitas standar dari selai yang diproduksi dengan bahan dasar kombinasi daging dan kulit buah naga merah. pertanyaan-pertanyaan dari partisipan tersebut.

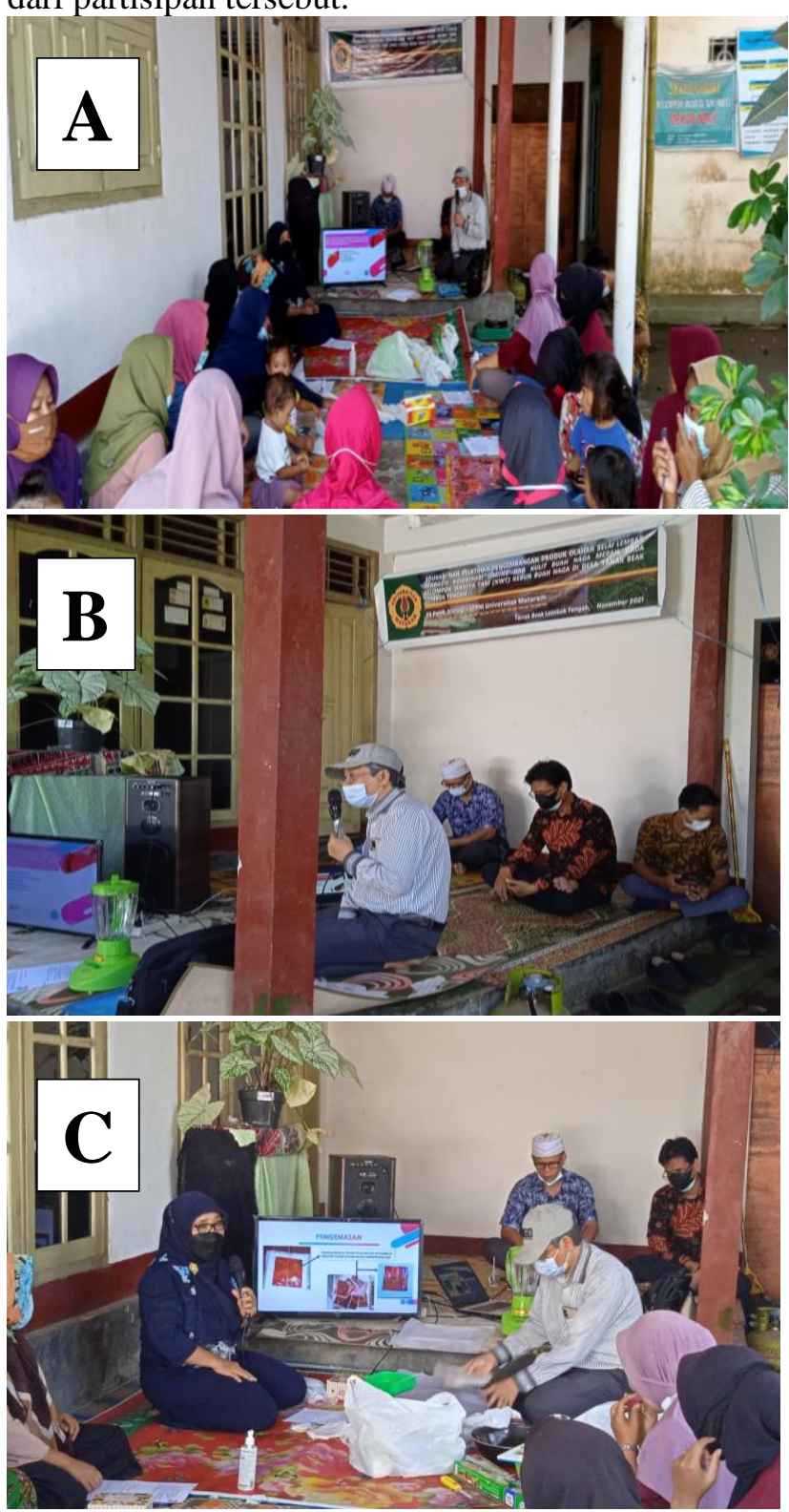

Gambar 1. Sosialisasi penanganan pasca panen buah naga dan diversifikasi produk olahan untuk meningkatkan nilai ekonomi produk (A, B); Uraian penjelasan prosedur pembuatan selai lembar berbahan dasar daging dan kulit buah naga (C). 


\section{Tahap Praktek pembuatan selai lembaran}

Dalam tahap praktek pembuatan selai lembar ini sebagian dari peserta langsung terlibat dari persiapan, pembuangan sisik, pemisahan daging
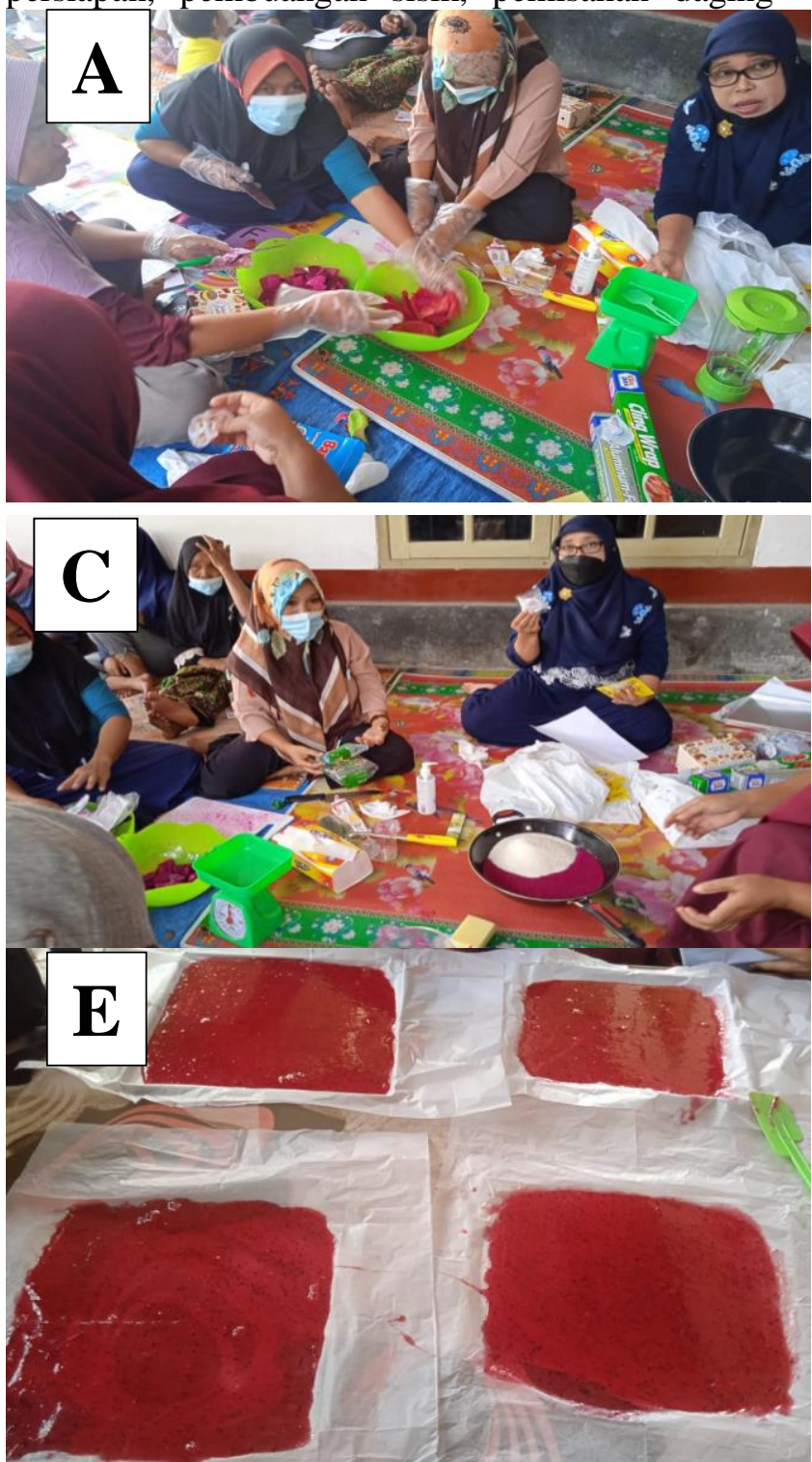

Gambar 2. Foto tahap utama pelaksanaan praktek pembuatan Selai lembar berbahan dasar kombinasi daging dan kulit buah naga merah. Pemisahan daging dan kulit, dan penimbangan agar proporsi sesuai perbandingan 70\%: 30\%) (A), penghalusan adonen dengan blender (B) pencampuran dengan air (50\% volume), gula (100\% berat awal bahan), agar/karagenan/pektin dan sitrun (C), dan pemasakan di atas kompor kira-kira 30 menit (D); Adonan dituang pada loyang dan diatur tingkat ketebalannya dan dibiarkan selama kurang lebih 40 menit pada suhu riang (E); Pemotongan sesuai ukuran roti tawar. 
Selanjutnya potongan selai dikemas dalam plastik kue steril (double layer) sebagai mana ditunjukkan pada gambar 3.

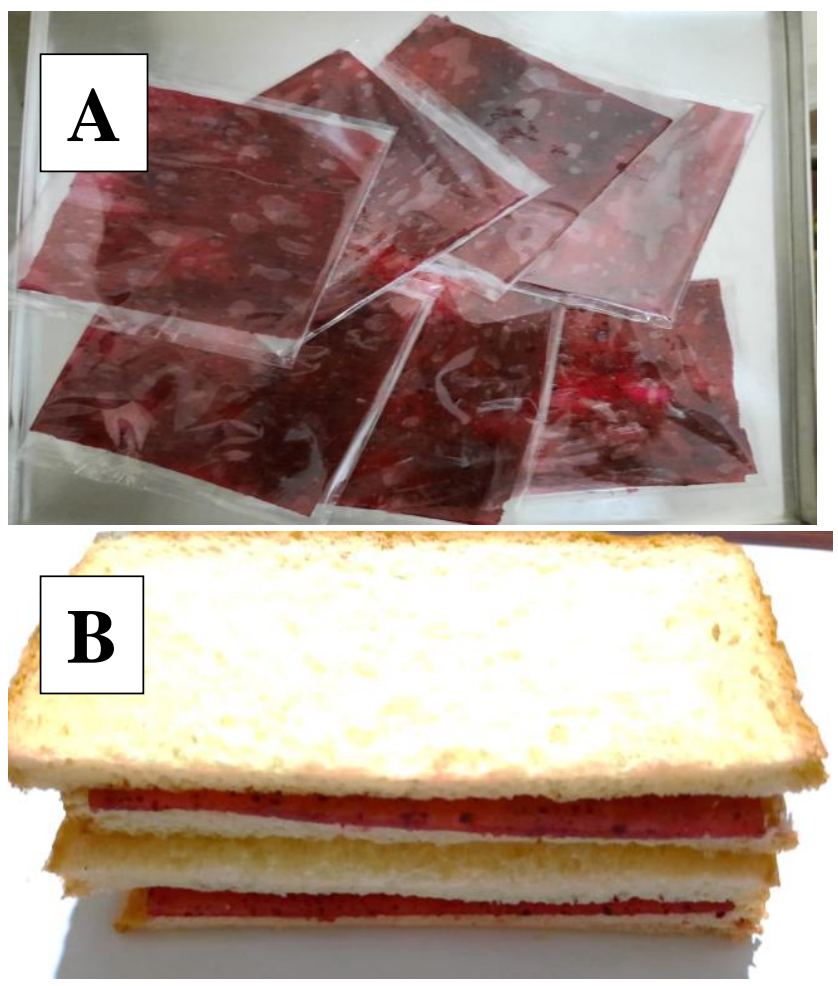

Gambar 3. Produk selai lembaran berbahan dasar kombinasi daging dan kulit buah naga merah (A); Penampakan produk selai lembaran ketika akan dikonsumsi bersama roti tawar (B).

\section{Tahap 3. Evaluasi terhadap kegiatan}

Pada tahap ini dilakukan tanya jawab dengan para peserta terkait kegiatan yang telah dilakukan dan dilakukan penutupan dan foto bersama dengan produk yang telah dihasilkan (Gambar 3). Dalam hal ini mereka memberi tanggapan yang sangat positif. Semua anggota KWT menyatakan akan melanjutkan pembuatan selai lembaran ini karena cukup sederhana dan dapat dilakukan dengan alatalat yang tidak mahal. Hasil selai lembaran yang diproduksi ini praktis dan higienis jika dikonsumsi bersama roti tawar. Hal ini berbeda dengan selai botolan yang banyak tersedia di pasaran cenderung dapat terkontaminasi karena adanya buka dan tutup botol dalam pemakaian yang berkali-kali.

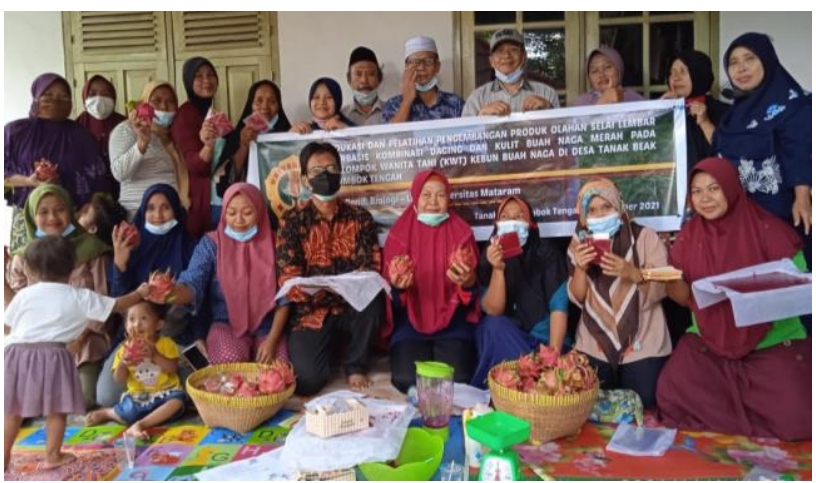

Gambar 4. Tahap Evaluasi dan penutupan acara pengabdian pada KWT Mekar Indah Desa Tanak Beak

Faktor pendorong keterlibatan masyarakat kelompok Tani Buah Naga adalah produksi yang berlebih buah naga di pulau Lombok menyebabkan turunnya harga di pasaran. Dalam kondisi seperti ini maka diperlukan pengetahuan dan keterampilan dalam penanganan dan pengolahan pasca panen buah naga merah. Salah satunya adalah dengan memproduksi selai lembaran berbasis daging dan kulit buah naga, sehingga semua komponen buah dapat dimanfaatkan. mengolah buah naga.

Hal lain yang menjadi faktor penting dalam hal ini adalah bahwa selai yang beredar di pasaran umumnya berbentuk selai oles. Hal ini dianggap kurang praktis dalam penyajiannya sehingga perlu pengembangan bentuk olahan lain, seperti selai lembaran yang sudah dipraktekkan oleh partisipan KWT kebun buah naga di atas. Selai lembaran lebih praktis dan lebih mudah dalam penyajiannya, sehingga menjadi alternatif utama produk pangan yang dapat dikonsumsi bersama roti.

Pada zaman modern ini, orang cenderung melakukan kegiatan berdasarkan tingkat kepraktisannya. Semakin tinggi tingkat kepraktisan suatu kegiatan, maka kegiatan tersebut cenderung lebih dominan untuk dipilih. Hal ini pun memiliki kesamaan dengan kegiatan makan roti. Menurut data Euromonitor, nilai konsumsi roti per kapita masyarakat Indonesia memiliki nilai pertumbuhan tertinggi dibandingkan 11 negara Asia Pasifik lainnya. Nilai konsumsi roti di Indonesia naik 25\% pada 2011 menjadi US \$1,5 per orang per tahun. Sedangkan, kebutuhan selai dalam mengonsumsi roti memiliki persentase belum terpenuhi sebesar $\pm 80 \%$.

Bahan pengolahan selai terdiri dari bahan baku dan bahan tambahan. Ketepatan dalam 
pengenalan dan pemilihan bahan akan mempengaruhi kualitas produk selai yang dihasilkan. Bahan bakunya yaitu: buah musiman yang produksinya melebihi kebutuhan sehingga dapat dijadikan alasan untuk pengolahan dengan daya simpan yang cukup panjang. Pengolahan selai buah dapat menggunakan berbagai tingkat kematangan buah. Buah setengah matang dapat memberikan cita rasa asam untuk memperbaiki konsistensi selai yang dihasilkan, sedangkan buah matang penuh dapat memberikan aroma yang diinginkan. Pencampuran kedua jenis kematangan buah tersebut dapat memberikan cita rasa selai yang lebih baik.

Produk selai lembaran yang baik adalah selai yang berbentuk lembaran sesuai permukaan roti, tidak cair atau terlalu lembek, namun juga tidak terlalu kaku sehingga diperlukan bahan tambahan berupa hidrokolid sebagai penguat tekstur, salah satunya adalah hidrokoloid turunan rumput laut merah yaitu agar-agar. Pemanfaatan rumput laut khususnya agar-agar sebagai bahan tambahan selai diharapkan mampu mengubah tekstur selai menjadi lembaran yang disukai.

Tim pengabdian berharap agar pengetahuan dan memberi keterampilan praktis anggota masyarakat, khususnya KWT buah naga Mekar Indah Desa Tanak Beak untuk membuat produk rumahan Selai Lembar Buah Naga Merah berbasis kombinasi daging dan kulit buah naga yang berkualitas untuk konsumsi sendiri dan juga dapat sebagai produk rumah tangga skala kecil yang dapat sebagai sumber tambahan penghasilan dalam menopang perekonomian keluarga.

\section{Kesimpulan}

Pelaksanaan program pengabdian masyarakat di Kelompok Wanita Tani (KWT) Mekar Indah di Dusun Dasan Agung Desa Tanak Beak Lombok Tengah telah berhasil dilakukan dengan baik. Selama kegiatan berlangsung, para partisipan mengikuti dengan seksama materi yang dijelaskan oleh tim baik yang menyangkut teori penanganan pasca panen buah naga dan praktek langsung pembuatan produk olahan kombinasi daging kulit buah naga sampai pada proses pengemasan. Hasil evaluasi dari kegiatan secara keseluruhan menunjukkan bahwa semua anggota KWT Mekar Indah akan melanjutkan keterampilan yang diperolehnya agar dapat menjadi usaha kecil yang dapat membantu perekonomian keluarga. Hal ini dimungkinkan karena ketersediaan bahan baku dan alat-alat yang diperlukan juga tersedia.

\section{Ucapan Terima Kasih}

Penulis mengucapkan terima kasih kepada Rektor Universitas Mataram yang telah memberi dukungan finansial terhadap pengabdian ini.

\section{Daftar Pustaka}

Agustina, W. 2009. Teknologi Pengemasan Desain dan Pelabelan Kemasan Produk Makanan. Di dakses Februari 2021 dari https://istanaumkm.pom.go.id/teknologiproses/pangan/teknologi-

Dara. Widia, Shinta, D.Y. dan Saputra, R., 2012. Pemanfaatan Limbah Kulit Buah Naga Merah (Hylocereus Costaricensis) Sebagai Pewarna Kerupuk Merah, Prosiding Seminar Perhimpunan Ahli Teknologi Pangan Indonesia Cabang Sumatera Barat2012 Food and Renewable Energy for Better Life. Agritech Press FakultasTeknologi Pertanian-Universitas Andalas.

Melina, M.M. 2016. Pengaruh Penggunaan Filtrat Kecambah Kacang Hijau Sebagai Sebagai Sumber Nitrogen Alternatif Terhadap Karakteristik pengemasan Nata de Besusu, Universitas Sanata Dharma, Yogyakarta.

Pribadi, Y, S., Sukatiningsih., Sari, P. 2014. Formulasi Tablet Evervecent Berbahan Baku Kulit Buah Naga Merah (Hylocereus polyrhizuz) dan Buah Salam (Syzygium polyanthum Wight. Walp). Berkala lmiah Pertnian. 1 (4).

Profil Desa Tanak Beak, 2018

Rahmawati, Fitri. 2013. Pengemasan dan Pelabelan. Materi Pelatihan Kewirausahaan bagi Kelompok UPPKS BPPM DIY. 9 -11 September 2013.

Sarasmita M.A; Laksmiani, N.P.L., 2015. Uji Sitotoksisitas Ekstrak Etanol Limbah Kulit Buah Naga Merah (Hylocereus polyrhizus) pada Sel Kanker Payudara Secara In Vitro dan In Silico. Jurnal Farmasi Udayana, [S.1.], dec. 2015. ISSN 2622-4607.

Sucipta I.N., Suriasih. IK., Kencana. PKD, 2017. Pengemasan Pangan Kajian Pengemasan Yang Aman, Nyaman, Efektif Dan Efisien, Unud Press. 